\title{
Structural biologist named president of UK Royal Society
}

Nobel laureate Venkatraman Ramakrishnan will replace Paul Nurse in December.

\section{Mark Peplow}

18 March 2015

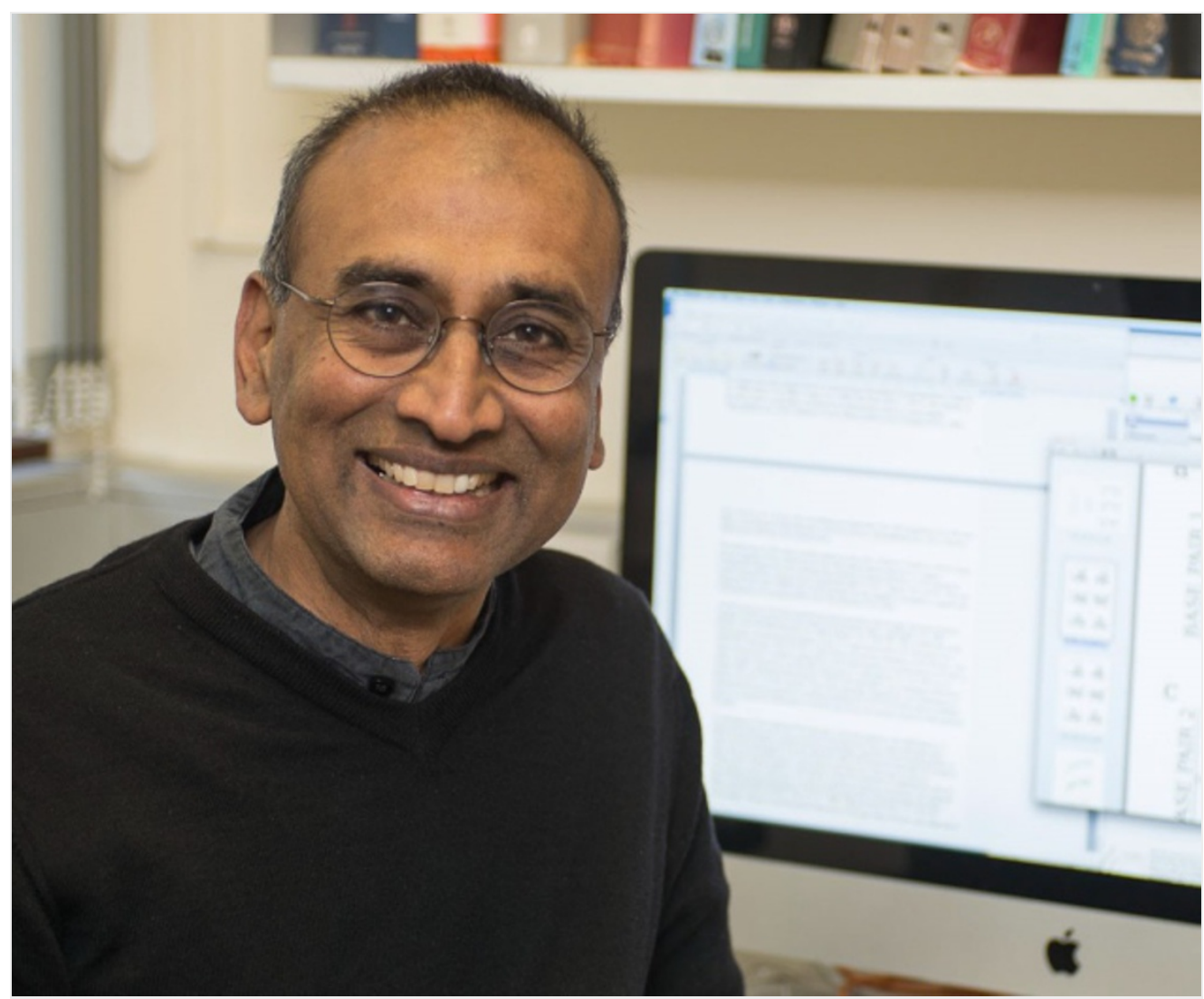

Neil Grant/MRC LMB Venki Ramakrishnan won a Nobel prize for work on the structure and function of the ribosome.

A Nobel-prizewinning structural biologist will be the next president of the Royal Society, the United Kingdom's pre-eminent scientific institution. Venkatraman (Venki) Ramakrishnan will take over from geneticist Paul Nurse, also a Nobel laureate, on 1 December.

"It's a great honour," Ramakrishnan told Nature's news team. "Paul has been an articulate and forceful advocate for science, and I can only do my best to continue that." 
was awarded a share in the Nobel Prize in Chemistry in 2009 for his work on the structure and function of the ribosome, a molecular machine that translates genetic information to build proteins.

"He's clearly got the scientific credentials," says James Wilsdon, a science-policy researcher at the University of Sussex in Brighton, UK, and former director of the Science Policy Centre at the Royal Society in London. "It's always a positive when the president comes with a Nobel prize."

The Royal Society was founded in 1660. As president, Ramakrishnan will have a unique and influential platform from which to speak out on science-policy issues, including the government's research budget. He differs from his three most recent predecessors - Nurse, astronomer Martin Rees and ecologist Robert May — in that he has a much lower profile in public and policy circles, says Wilsdon: "There's less of a sense of what his vision will be."

\section{Global reach}

Ramakrishnan grew up in India and has spent the majority of his research career in the United States, moving to the United Kingdom in 1999. He has a diverse scientific background: he switched to biology after a PhD in physics. "That breadth is something I hope will help me," he says.

His international connections could help to expand the Royal Society's links abroad, encouraging collaborations with other national academies around the world to speak with one voice on key policy issues such as climate change. "Venki embodies the cosmopolitan nature of contemporary science," says Wilsdon.

Nurse has been president of the Royal Society since 1 December 2010. Many of his scientific colleagues regard him as a particularly adept administrator who is unafraid to speak out on science policy. "Paul combines great academic strength with down-to-Earth affability," says Wilsdon. "He's been a very effective leader and ambassador for science."

Nurse is currently leading a government review of the UK Research Councils, which distribute much of the government's funding for research. He has also been willing to challenge politicians, arguing passionately that their anti-immigration rhetoric is damaging the United Kingdom's ability to recruit leading scientists from abroad. He has described as "cowardly" those politicians who ignore scientific evidence that supports unpopular policy decisions — for example, on the legislation against recreational drugs — and called for broader acknowledgement of the benefits of the United Kingdom's membership of the European Union.

After Nurse hands over the presidency, he will continue his role as director and chief executive of the Francis Crick Institute, a £650-million (US\$1-billion) biomedical-research centre in London that is scheduled to open later this year.

\section{Critical voice}

Ramakrishnan will take office at a time of increasing debate about research funding, predicts Wilsdon. Over the past five years, the United Kingdom has seen no major increases in its science budget, and research spending has declined as a proportion of gross domestic product. The UK Campaign for Science and Engineering, a pressure group, says that the annual science budget has fallen by $£ 1$ billion in real terms since 2010.

Tight science funding is expected to continue in the next parliament, whatever the outcome of the country's next general election, in May. "The president is a critical voice in those debates," says Wilsdon.

Ramakrishnan is reluctant to discuss his goals for his presidency, but is confident that he can represent the diverse views of the Royal Society's roughly 1,600 Fellows. "I think I'm a good listener," says Ramakrishnan, adding with a chuckle, "at least, l'll have to be."

Nature | doi:10.1038/nature.2015.17153

Nature ISSN0028-0836 ESSN 1476-4687

\section{SPRINGER NATURE}

(C) 2019 Macmillan Publishers Limited, part of Springer Nature. All Rights Reserved. partner of AGORA, HINAR, OARE, INASP, OrossRef and COUNIER 